\title{
An Empiric Study in the Effectiveness of Student Training Based on Organizational and Pedagogical Conditions of Mobile Learning
}

\author{
Aleksandr Volodin \\ Moscow Region State University \\ Moscow, Russia \\ E-mail: voalan@rambler.ru
}

\author{
Natalia Bondarenko \\ Tula Institute of Management and Business. ND Demidov \\ Tula, Russia \\ E-mail: joyful13@yandex.ru
}

\author{
Andrei Volodin \\ Moscow Institute of Humanities \\ Moscow, Russia \\ E-mail: volodinand@mail.ru
}

\begin{abstract}
The paper reports on the contents of the empirical research on the evaluation of the effectiveness of the student training based on organizational and pedagogical conditions of the mobile learning. We specify the stages and the content of the experiment as well as its conditions and sampling. The sample consists of students enrolled in the programme of higher professional education 40.04.01 "Law". For evaluation of the students' learning outcomes organizational and pedagogical conditions of the mobile learning the authors employ various test banks developed for the experiment. The data collected during the experiment are processed and analyzed with help of Student's t-test.
\end{abstract}

Keywords—experiment; evaluation methods; mobile learning; m-learning

\section{INTRODUCTION}

The practice of modern innovational development in Russia is conditioned by the need in improving the socioeconomic system of the country. Following this strategic direction in various public domains is put down to the development of priority research areas, technologies and engineering in the RF. Information and telecommunication systems and technologies are well integrated into numerous life spheres including the education system. Such a process is facilitated by external conditions connected with the informatization of the society as well as by internal ones determined by the expansion of up-to-date PCs and other multimedia devices in educational organizations and in private hands (laptops, smartphones and tablets), data telecommunications network and software.

According to the international research «Mobile thinking» [15] as late as in 2013, 6 billion 800 million people (96\% of the world population) were in possession of a mobile phone; about 1 billion 877 million people in the world had access to the mobile internet using high bitrate access 3G/LTE. Besides, the statistics of Q3 of 2015 г. suggest that LTE coverage exceeds $70 \%$ in 21 countries while for 53 countries it is at least $50 \%$ coverage. Thus, LTE networks, as a rule, are accessible in most countries [9]. These figures demonstrate that a considerable number of countries boast high bitrate mobile internet access.

It has become evident that mobile devices (telephones, smartphones, tablets, virtual vision glass, smart watch and other gadgets) are widely used in the education sector. They are available to most learners in Russia. However, the integration of these devices into the process of education is rather slow in comparison with many countries-leaders in implementing mobile learning. In the document «Mobile learning for quality education and social inclusion» [14] published in 2010 by the UNESCO Institute for Information Technologies in Education, it is stated that educators cannot ignore the obvious fact of a growing popularity of mobile devices with young people, which is a prerequisite for analyzing how mobile means of communication and mobile technologies can enhance the effectiveness of the education process and prove indispensable in reaching pedagogical goals.

It can be claimed that mobile learning, originated in the 21 st century, employs mobile wireless devices, the rapid upgrading and expansion of which are progressing as means of learning. Special attention should be drawn to the fact that the development of mobile devices is accompanied by a rapid sprawl of information and telecommunication networks with high bit-rate internet access, which increases opportunities of mobile device application in the learning process and provides access to learning resources at best time available.

In this connection the study of organizational and pedagogical conditions that enable effective integration of innovative ICT and technologies of mobile learning into the 
education process proves a pressing issue. The objective of the study is to enhance quality and student training effectiveness in high educational establishments.

The theoretical research conducted by the authors reveals general and essential characteristics of the key notions of the research problem and defines them as follows:

- Organizational and pedagogical conditions - a characteristic of the pedagogical system that reflects a unity of opportunities of material, space and educational environment, the realization of which provides organized, effective and purposeful functioning, as well as the development of the pedagogical system;

- Mobile learning - a principled process of active and interactive communication of learners by means of a didactic information and communication technology that possesses specified opportunities for implementing methods and forms of instruction. This technology has a specified character of presenting the educational programme as learning content and enables a student, irrespective of the location and time of learning, to achieve educational goals and pre-planned learning outcomes [20].

Today mobile learning in Russia is under the spotlight of the pedagogical science and practice. The application of mobile learning in the process of student training at educational establishments is to be based on pedagogically tested approaches and teaching methods. For this purpose the analysis includes, but is not restricted to, foreign scholarship on the problem of mobile learning. There is enough scholarship on computerization and using information and communication technologies in the process of education.

The demand search for «m-learning» and specification «education educational research», in the Web of Science for the last five years shows 209 publication references (dated 02.05.2016 г.). The analysis of the publications for the indicated period demonstrates that studying various organizational and pedagogical conditions of mobile learning is becoming one of the key trends in the sphere of mobile learning implementation.

In the context of the present work we consider the research of the following interesting:

- Factors that encourage successful integration of mobile learning at university [2], including administrative factors; those connected with grownups' prevailing reasons for learning (cognitive, emotive and social) [12], factors related to schoolchildren's and educators' attitude to mobile learning [16];

- Interconnection of learning material presentation on the smartphone and conditions of evoking learners' interest, concentration and achievements [22];

- Pedagogical conditions and peculiarities of mobile learning implementation in the context of distance education in the process of extracurricular activity [17];

- Students' evaluation of IPAD application in the course of field practical training and awareness of application peculiarities of this learning tool under the present conditions [21];

- Peculiarities of controlling learners' attention in the course of mobile device application in class [18];

- Didactic opportunities and the choice of game mobile applications for teaching schoolchildren $[8$, $11]$

- Issues of using mobile learning in teacher training [5];

- The connection between using mobile telephones and the quality of preparing home assignments by students [13];

- Opportunities and problems of developing technological platforms for mobile learning and syllabus design [10].

In accordance with the suggested and tested hypothesis of the research, if organizational and pedagogical conditions of mobile learning are integrated into the teaching process at university, it improves students' level of training.

\section{ORGANIZATION OF EMPIRICAL OBSERVATION}

For testing the suggested hypothesis we did an empirical research in the form of a pedagogical experiment aimed at the performance evaluation and testing of the educational programme of training Masters of Law based on the organizational and pedagogical conditions of mobile learning [20]. The assessment tool for performance evaluation is the level of the students' learning outcomes.

The conducted experiment included three stages: ascertaining experiment, formative experiment and analytical experiment. At the ascertaining stage of the pedagogical experiment we set the following tasks: formation of the student body (check sample and experimental sample), assessment methods selection and statistical processing of the results.

The samples were formed by randomizing technique. We filtered 2 samples ( 1 of the control group and 1 of the experimental group). The sample consisted of 46 first-year students, all of which are enrolled in the programme of higher professional education 40.04.01 "Law" "Table I".

TABLE I. EXPERIMENT PARAMETERS

\begin{tabular}{|c|c|c|c|c|c|c|}
\hline \multirow[b]{2}{*}{ № } & \multirow[b]{2}{*}{ Discipline } & \multirow[b]{2}{*}{ ECTS } & \multirow[b]{2}{*}{$\begin{array}{l}\text { Ye } \\
\text { ar }\end{array}$} & \multicolumn{2}{|c|}{ Sample size } & \multirow{2}{*}{$\begin{array}{c}\text { Evalua } \\
\text { tion } \\
\text { tool }\end{array}$} \\
\hline & & & & $\begin{array}{c}\text { contr } \\
\text { ol }\end{array}$ & $\begin{array}{l}\text { experi } \\
\text { mental }\end{array}$ & \\
\hline 1 & $\begin{array}{l}\text { "Important } \\
\text { Problems of the } \\
\text { Civil Law" }\end{array}$ & 4 & 1 & \multirow{2}{*}{22} & \multirow{2}{*}{24} & Test \\
\hline 2 & $\begin{array}{l}\text { "Contract Law: } \\
\text { Important Issues and } \\
\text { Court Practice" }\end{array}$ & 4 & 1 & & & Test \\
\hline
\end{tabular}


The experimental groups were taught some of the disciplines of the curriculum with the use of mobile learning. The control groups were taught the same disciplines without mobile learning.

The validity of the sample comparison (the experimental and control groups) according to the criteria was conditioned by the fact that all the groups had the same curriculum classes; the time allocated for each discipline was identical; classes were organized in the same conditions and with identical evaluation tools for grading students and measuring learning outcomes.

The fact that no preparatory training in the disciplines was conducted was taken into account as well. Therefore, we may assume the equality of the samples (student groups) under consideration [3]. The difference lay in using mobile learning in the course of student training in the experimental group. In the control group no mobile learning was applied.

We evaluated the effectiveness of the educational programme in the course of training students based on organization and pedagogical conditions of mobile learning with help of computer testing using test banks.

All evaluation tools were developed by the academic teaching staff in charge of higher education programme 40.04.01 "Law". The test banks for the disciplines "Important Problems of the Civil Law" and "Contract Law: Important Issues and Court Practice" were developed according to the principles described in the researches $[4,6$, $7,19]$. The instrument used for testing and processing the results was the software tool "Adaptive Test Environment ACT".

\section{THE FORMING EXPERIMENT}

At the forming stage of the pedagogical experiment we taught the students and graded their work according to the disciplines of the high education programme 40.04.01 "Law". We taught the students taking into account organizational and pedagogical conditions of mobile learning. The educational programme is built on the authors' method of syllabus design.

The essence of this educational programme is the structure of the educational programme of student training in conditions of using organizational and pedagogical methods of mobile education. The employed method develops itself through the description of the syllabus design at every level of the educational programme [20].

\section{DISCUSSION}

At the analytical stage of the pedagogical experiment we used statistical analysis and interpreted the students' grading results. We present the statistic processing and interpretation results of the students' grading using Student's t-criterion and formulate the null $(\mathrm{H} 0)$ and alternative (H1) hypotheses of the statistical check: H0, the average level of the learning outcomes in the control and experimental groups, is statistically similar. $\mathrm{H} 1$, the average level of the learning outcomes in in the control and experimental groups, is statistically dissimilar.

According to the calculation methodology [1, C. 139154], we adopt $\mathrm{p}$-level 5\% $(\mathrm{p}=5 \%)$, i.e. we adopt the risk of error in the output in five out of one hundred cases at testtakers' random sampling for each experiment.

Based on the results of the students' tests from the experimental and control groups, we made an automated calculation of Student's t-distribution "Table II".

TABLE II. The CALCUlation Results of Statistical VAlue of STUDENT'S T-DISTRIBUTION

\begin{tabular}{|l|l|l|l|l|}
\hline \multicolumn{1}{|c|}{ Discipline } & \multicolumn{2}{|c|}{$\begin{array}{c}\text { Important Problems of } \\
\text { the Civil Law }\end{array}$} & \multicolumn{2}{c|}{$\begin{array}{c}\text { Contract Law: } \\
\text { Important Issues and } \\
\text { Court Practice }\end{array}$} \\
\hline $\begin{array}{l}\text { Critical } \\
\text { value t }\end{array}$ & $\mathrm{p} \leq 0.05$ & $\mathrm{p} \leq 0.01$ & $\mathrm{p} \leq 0.05$ & $\mathrm{p} \leq 0.01$ \\
\cline { 2 - 5 } $\begin{array}{l}\text { Empirical } \\
\text { value t }\end{array}$ & 2.01 & 2.41 & 2.01 & 2.41 \\
\hline
\end{tabular}

The differences discovered between the control and experimental samples are significant more than at the fivepercent level, i.e. the average level of the students' learning outcomes in the disciplines "Important Problems of the Civil Law" and "Contract Law: Important Issues and Court Practice" in the experimental group is higher than that in the control group. In terms of statistic hypotheses this statement reads as follows: hypothesis $\mathrm{H} 0$ on identity is rejected, and at the $5 \%$ level an alternative hypothesis $\mathrm{H} 1$ on the difference between the experimental and control groups is accepted.

The statistical analysis of the students' grading results demonstrates that the learning outcomes in the experimental group are better than in the control one. This result is put down to the stepped-up action and convenience of the students' independent learning activity organization, which can be observed through the analysis of the conducted survey with the students of the experimental group.

\section{CONCLUSION}

The statistical analysis of the students' grading results demonstrates that the learning outcomes in the experimental groups are higher than in the control ones. Thus, we make a conclusion that teaching students enrolled in the programme of higher education 40.04.01 "Law" based on organizational and pedagogical conditions of mobile learning promotes them more effectively in learning the disciplines than without organizational and pedagogical conditions of mobile learning. Having regard to the above, we affirm that the suggested hypothesis is justified.

\section{RECOMMENDATIONS}

The results of the research provide a theoretical and methodical basis for solving urgent theoretical and practical problems of using innovative ICT in education. Further research in the field can be carried out in accordance with the immediate prospects of developing new mobile devices and ICT in education; providing organizational and pedagogical grounds for introducing and improving ICT in education. 


\section{REFERENCES}

[1] Alrasheedi, M (Alrasheedi, Muasaad); Capretz, LF (Capretz, Luiz Fernando); Raza, A (Raza, Arif). Management's Perspective on Critical Success Factors Affecting Mobile Learning in Higher Education Institutions-An Empirical Study // Journal of Educational Computing research. APR 2016. Vol. 54. Rel. 2. P. 253-274. DOI: $10.1177 / 0735633115620387$

[2] Alrasheedi, M (Alrasheedi, Muasaad); Capretz, LF (Capretz, Luiz Fernando); Raza, A (Raza, Arif). A Systematic Review of the Critical Factors for Success of Mobile Learning in Higher Education (University Students' Perspective) // Journal of Educational Computing research. APR 2015. Vol. 52. Rel. 2. P. 257-276. DOI: $10.1177 / 0735633115571928$

[3] Avanesov, VS. The application of statistical methods and computers in educational research // Introduction to the scientific study of pedagogy: a tutorial for students ped. Ying-ing / ed. IN AND. Zhuravlev. MA: Education, 1988, pp 139-154.

[4] Avanesov, VS. Theoretical Foundations of development tasks in the test form. Moscow: Higher School, 1995. 56 p.

[5] Baran, E (Baran, Evrim). A Review of Research on Mobile Learning in Teacher Education // EDUCATIONAL TECHNOLOGY \& SOCIETY. OCT 2014. Vol. 17. Rel. 4. P. 17-32.

[6] Chelyshkova, MB. Theory and practice of designing of pedagogical tests: Textbook. Moscow: Logos, 2002. 432 p.

[7] Chelyshkova, MB; Savelyev, BA. Guidelines for the development of tests for a comprehensive fitness of students in high school. Moscow: Higher School, 1995. 41 p.

[8] Chen, CP (Chen, Cheng-Ping); Shih, JL (Shih, Ju-Ling); Ma, YC (Ma, Yi-Chun). Using Instructional Pervasive Game for School Children's Cultural Learning // EDUCATIONAL TECHNOLOGY \& SOCIETY APR 2014. Vol. 17. Rel. 2 SI. P. 169-182.

[9] DeviceAtlas. The Mobile Web Report Q4, 2015 [http://discover.deviceatlas.com/mobile-web-report-q42015/?utm_source=mobiforge\&utm_medium=display $\% 20$ ads \&utm campaign=mobile-web-report-q4-2015]

[10] Dirin, A (Dirin, Amir); Nieminen, M (Nieminen, Marko). Managing m-learning application development: Roles and Responsibilities // PROCEEDINGS OF THE 2014 INTERNATIONAL CONFERENCE ON ADVANCED ICT, (ICAICTE 2014). P. 76-80.

[11] Green, LS (Green, Lucy Santos); Hechter, RP (Hechter, Richard P.); Tysinger, RD (Tysinger, R. Dawn); Chassereau, KD (Chassereau, Karen D.). Mobile app selection for 5th through 12th grade science: The development of the MASS rubric // COMPUTERS \& EDUCATION. JUN 2014. Vol. 75. P. 65-71. DOI: 10.1016/j.compedu.2014.02.007

[12] Hashim, KF (Hashim, Kamarul Faizal); Tan, FB (Tan, Felix B.); Rashid, A (Rashid, Ammar). Adult learners' intention to adopt mobile learning: A motivational perspective // BRITISH JOURNAL OF EDUCATIONAL TECHNOLOGY. MAR 2015. Vol. 46. Rel. 2 SI. P. 381-390. DOI: $10.1111 /$ bjet.12148

[13] Ilic, P (Ilic, Peter). The Relationship between Students, Mobile Phones and Their Homework // MOBILE AS MAINSTREAMTOWARDS FUTURE CHALLENGES IN MOBILE LEARNING, MLEARN 2014. Vol. 479. P. 146-155.

[14] Mobile learning for quality education and social inclusion [http://iite.unesco.org/files/policy_briefs/pdf/en/mobile_learning.pdf]

[15] Mobile thinking [http://mobithinking.com/mobile-marketingtools/latest-mobile-stats/a]

[16] Ozdamli, F (Ozdamli, Fezile); Uzunboylu, H (Uzunboylu, Huseyin). M-learning adequacy and perceptions of students and teachers in secondary schools // BRITISH JOURNAL OF EDUCATIONAL TECHNOLOGY. JAN 2015. Vol. 46. Rel. 1. P. 159-172. DOI: 10.1111/bjet.12136

[17] Reychav, I (Reychav, Iris); Dunaway, M (Dunaway, Mary); Kobayashi, M (Kobayashi, Michiko). Understanding mobile technology-fit behaviors outside the classroom // COMPUTERS \& EDUCATION. SEP 2015. Vol. 87. P. 142-150. DOI: 10.1016/j.compedu.2015.04.005
[18] Starkova, D (Starkova, Dagmar); Rusek, M (Rusek, Martin). The Use of M-Technology in Problem, Inquiry and Project-Based Education // PROJEKTOVE VYUCOVANI V PRIRODNICH PREDMETECH, 2014. P. 85-91

[19] Vasilyev, VI; Tyagunova, TN. Basics culture adaptive testing. M: Icarus, 2003. $584 \mathrm{p}$

[20] Volodin, AA; Bondarenko, NG. Organizational-pedagogical conditions of mobile learning: Monograph. Podolsk: Mogi, 2014. 102 p.

[21] Welsh, KE (Welsh, Katharine E.); Mauchline, AL (Mauchline, Alice L.); Powell, V (Powell, Victoria); France, D (France, Derek); Park, JR (Park, Julian R.); Whalley, WB (Whalley, W. Brian). Student perceptions of iPads as mobile learning devices for fieldwork // Jornal of Geography in Higher Education. JUL 3 2015. Vol. 39. Rel. 3. P. 450-469. DOI: 10.1080/03098265.2015.1066315

[22] Yang, XM (Yang, Xianmin); Li, XJ (Li, Xiaojie); Lu, T (Lu, Ting) Using mobile phones in college classroom settings: Effects of presentation mode and interest on concentration and achievement // COMPUTERS \& EDUCATION. OCT 2015. Vol. 88. P. 292-302. DOI: 10.1016/j.compedu.2015.06.007 